УДК 664:678.049.4

\title{
CURRENT SITUATION AND PROSPECTS OF ORGANIC PRODUCTS MARKET DEVELOPMENT IN UKRAINE AND THE WORLD
}

\author{
I. Vlasenko, T. Semko \\ Vinnitsa Trade and Economic Institute of Kyiv National University \\ of Trade and EconomicsN. Volodchenkova \\ G. Polishcuk, M. Borova \\ National University of Food Technologies
}

\begin{tabular}{|c|c|}
\hline Key words: & ABSTRACT \\
\hline $\begin{array}{l}\text { healthy food, } \\
\text { agrarian sector, } \\
\text { food industry, } \\
\text { organic production, } \\
\text { organic produce }\end{array}$ & $\begin{array}{l}\text { The purpose of the research is to analyze the current state } \\
\text { and identify the main directions of further development of orga- } \\
\text { nic production in Ukraine and the world. } \\
\text { The object of study is organic production. The article presents } \\
\text { the history of the domestic branch of organic production, its for- }\end{array}$ \\
\hline $\begin{array}{l}\quad \text { Article history: } \\
\text { Received } 13.03 .2020 \\
\text { Received in revised form } \\
\text { 17.04.2020 } \\
\text { Accepted } 12.05 .2020\end{array}$ & $\begin{array}{l}\text { mation and peculiarities of adaptation to the requirements of the } \\
\text { world market are given. The main tasks of the industry as a com- } \\
\text { plete system of management and production of food raw materials } \\
\text { and food are outlined. The urgency of organic production in many } \\
\text { countries of the world and Ukraine has been proved, which has all }\end{array}$ \\
\hline $\begin{array}{l}\text { Corresponding author: } \\
\text { milknuft@i.ua }\end{array}$ & $\begin{array}{l}\text { the prerequisites to become one of the leaders in organic production. } \\
\text { The achievements of organic production in Ukraine in recent years } \\
\text { are presented and its great potential in this sphere of economic } \\
\text { activity is proved. Requirements on quality and peculiarities of or- } \\
\text { ganic production, the main criteria for its choice by consumers and } \\
\text { place in the healthy lifestyle system are highlighted. } \\
\text { The main problems that impede the further development and } \\
\text { comprehensive progress of organic production are specified. The } \\
\text { most significant factors that significantly impede the development } \\
\text { of the organic market in Ukraine have been identified. Specific } \\
\text { measures are outlined to address practical challenges in the organic } \\
\text { production sector, which are recommended for widespread adop- } \\
\text { tion. In particular, the need to strengthen state support at the le- } \\
\text { gislative level, the use of international organic production expe- } \\
\text { rience, and the promotion of healthy lifestyles, including healthy, } \\
\text { safe and organic food in highly developed countries, are highlited. } \\
\text { It is proved that the implementation of the recommended mea- } \\
\text { sures will comprehensively develop the market of organic produce, } \\
\text { increase its export attractiveness, have social significance and sa- } \\
\text { tisfy the need for healthy nutrition of domestic consumers. }\end{array}$ \\
\hline
\end{tabular}

DOI: $10.24263 / 2225-2916-2020-27-6$

(C) I. Г. Власенко, Т. В. Семко, Г. Е. Поліщук, М. П. Борова, 2020 


\title{
СУЧАСНИЙ СТАН I ПЕРСПЕКТИВИ РОЗВИТКУ РИНКУ ОРГАНІЧНОЇ ПРОДУКЦІЇ В УКРАЇНІ ТА СВІТІ
}

\author{
І. Г. Власенко, д-р мед. наук \\ Т. В. Семко, кнд. техн. наук \\ Вінницький торговельно-економічний інститут КНТЕУ \\ Г. Є. Поліщук, \\ М. П. Борова \\ Національний університет харчових технологій
}

Метою наукового дослідження $є$ аналіз сучасного стану та визначення напрямків розвитку виробництва органічної продукції в Україні та світі. У статmі описано історію виникнення вітчизняної галузі органічної продукції, їі становлення та особливості адаптації до вимог світового ринку. Окреслено основні завдання галузі як цілісної системи господарювання та виробництва продовольчої сировини і харчових продуктів. Доведено актуальність виробництва органічної продукції у багатьох країнах світу та Україні, яка має всі передумови увійти до числа лідерів $з$ органічного виробництва. Наведено досягнення органічного виробництва в Україні за останні роки та доведено його значний потениіал у цій сфері економічної діяльності. Доведено, що реалізація рекомендованих заходів з виробництва органічної продукції розвиватиме ринок органічної продукції, підвищуватиме його експортну привабливість, матиме соціальну значимість і задовольнятиме потребу у здоровому харчуванні вітчизняних споживачів.

Ключові слова: здорове харчування, аграрний сектор, харчова промисловість, органічне виробництво, органічна продукція.

Постановка проблеми. Останнє десятиріччя характеризується суттєвим порушенням екологічної рівноваги в багатьох країнах світу, що $є$ наслідком надмірної експлуатації природних і невідновлюваних ресурсів та широкого застосування засобів захисту рослин і мінеральних добрив [1]. Одним із сучасних напрямків вирішення вказаної проблеми в Україні є органічне виробництво сільськогосподарської продукції та харчових продуктів, яке підвищує інтерес імпортерів до української продукції та сприяє покращенню структури харчування населення. Питання сучасного стану виробництва органічної продукції висвітлювались у працях багатьох вітчизняних вчених. Так, за даними аналітичних досліджень I. А. Білоткач і М. П. Мартинюк конкретизовано основні аспекти формування і розвитку ринку органічної продукції в Україні та підтверджено провідну роль державного регулювання у сфері органічного виробництва [2; 3]. С. В. Миловановим, Н. Ю. Бугою та I. Г. Яненковою досліджено сучасний стан органічного виробництва та розглянуто підходи до регіональної підтримки органічного виробництва [4; 5]. Проте в наведених дослідженнях відсутня практична складова, яка б конкретизувала дієві заходи, спрямовані на подальший розвиток вітчизняного органічного виробництва. Натомість у Данії проаналізовано причини вибору споживачами органічної продукції у цій країні як задоволення потреб суспільства в здоровому способі життя, підтверджено актуальність подальших досліджень у сфері розвитку органічного ринку та окреслено їх напрями [6]. Шведськими вченими встановлено, що нарівні 3 домінуючою «концепцією інтенсивного органічного землеробства» у Свропі зароджується нова «концепція екології харчових систем», яка відрізняється ще вагомішим соціальним значенням [7]. 
Отже, ситуація на ринку органічної продукції за постійно зростаючого попиту на неї змінюється дуже динамічно. Саме тому важливо вивчати та аналізувати сучасний стан розвитку цього сектору виробництва, що надасть можливість розроблювати успішні кроки для ефективного й оперативного подолання існуючих проблем.

Метою дослідження $є$ аналіз сучасного стану та визначення конкретних заходів щодо подальшого ефективного розвитку вітчизняного органічного виробництва.

Результати досліджень. Термін «органічне сільське господарство» був вперше застосований у 1940 р. лордом Нортборном у книзі «Погляд на землю», де він описав цілісний та екологічно збалансований підхід до організації «зеленого» землеробства [8]. У той же час нині існує багато несистематизованої інформації про особливості розвитку органічного виробництва та його вплив на структуру харчування населення різних країн світу. Узагальнено наявні дані про вплив органічної їжі на здоров'я людини та конкретизовано потенційну роль нормативних вимог країн СС в управлінні виробництвом і якістю органічних продуктів [9]. Доведено, що основними відмінностями складу між органічними та звичайними культурами є дещо більший вміст фенольних сполук в органічних фруктах і овочах та менший вміст кадмію в органічних зернових культурах, а органічні молочні продукти і м'ясо містять більше жирних кислот омега-3.

Б. Швендель та ін. взагалі рекомендують не робити однозначні висновки щодо відмінностей складу між молоком органічним і традиційно одержуваним через існування занадто великої кількості чинників впливу на його хімічний склад [10]. Більшу стурбованість викликає поширене застосування антибіотиків у традиційному тваринництві, на відміну від органічного виробництва. Тож доволі раціональні органічні методи виробництва можуть бути корисними для впровадження у традиційне сільське господарство.

Однак деякі американські вчені доволі критично ставляться до органічного виробництва і стверджують, що терміни «органічний», «натуральний» та «автентичний» стосовно харчових продуктів, виготовлених у малих цехах, ресторанах, крафтових майстернях, іноді маскують їхню низьку якість та безпечність за значно вищої ціни [11]. Міністр сільського господарства США Ден Глікман (2000р.) взагалі стверджував, що поняття «органічний» — це маркетинговий інструмент, метою якого $є$ підвищення прибутку для виробників без гарантії безпеки харчового продукту. Було встановлено, що більшість органічних фруктів та овочів не $є$ більш поживними, ніж їхні дешевші аналоги, а перевагою термічно оброблених неорганічних продуктів $є$ відсутність патогенних бактерій. За ведення органічного землеробства неминучими $є$ не лише низькі врожаї, але й підвищення потреби у землі, воді та механічному обробленні грунтів, що може призвести до суттєвих екологічних проблем. Отже, органічне землеробство та виробництво органічних харчових продуктів не сприймається суспільством однозначно, тому його слід впроваджувати лише в умовах підприємств харчової та переробної промисловості з обов'язковим контролюванням відповідності вимогам до якості сировини та суворим дотриманням усіх рекомендацій і правил оброблення, фасування та зберігання готової органічної продукції.

Незважаючи на вказані вище проблеми, органічні продукти стають все білыш популярними і широкодоступними за щорічно зростаючих обсягів виробництва і продажу. Цей феномен пояснюється тим, що з кожним роком все більшим стає прагнення людей до здорового харчування та вживання корисних та екологічно чистих продуктів. Так, якщо у 1999 р. під органічне землеробство було зайнято 
усього 11 млн га, то у 2014 р. цей показник зріс у 4 рази. У 10 разів зросла кількість виробників органічної продукції [12; 13]. За даними Organic World, станом на 2016 р. [14] у світі із 230 країн світу органічним виробництвом займалися 178 країн (77\% від загальної кількості). Лідерами залишаються країни СС - iз 49 країн 48 охоплено органічним виробництвом. Активно впроваджують органічне виробництво країни Азії, де органічне виробництво зосереджено в 41 країні $(83,7 \%)$. У той же час загальна площа органічних сільськогосподарських угідь у світі залишається незначною і досягає всього 1,2\% від обсягу всієї площі. Найбільша частка площ органічних земельних угідь належить Австралії (35,6 млн га), Аргентині (3,4 млн га) і Китаю (3 млн га). Найбільший ринок органічної продукції належить США (45,6 млрд дол. США), Німеччині (11,3 млрд дол. США) та Франції (8,9 млрд дол. США). За споживанням органічної продукції на душу населення лідирують Швейцарія, Данія та Швеція. Позитивна тенденція розвитку органічного виробництва у світі зберігається і в 2020 р. ¡12; 13$\rceil$.

В Україні у 2005 р. було засновано Федерацію органічного руху, функцією якої $\epsilon$ сприяння розвитку сучасних, ефективних і безпечних для довкілля і людини технологій ведення сільського господарства. Але офіційне запровадження органічного виробництва розпочалося з укладання договору між Україною та Швейцарією. Перший вітчизняний сертифікаційний орган — компанію «Органік Стандарт» було створено в рамках українсько-швейцарського проекту «Органічна сертифікація та розвиток органічного ринку в Україні» у 2007 році. Компанія здійснює сертифікацію в усіх регіонах України для понад 400 операторів органічної продукції, що складає близько 75\% від усіх органічних операторів в країні. Завдяки тому, що «Органік Стандарт» визнано у Європі та Швейцарії, клієнти цієї компанії можуть експортувати свою продукцію до СС за спрощеною схемою. Вже з 2010 p. 3'явилися власні підприємства 3 переробки органічної сировини і внутрішній вітчизняний ринок почав наповнюватися органічною продукцією - зерновими, фруктами, м'ясними та молочними продуктами, медом тощо [15].

У 2011 р. в Україні було прийнято Закон «Про органічне виробництво», який регламентував вимоги до всіх етапів виробництва, переробки та постачання кінцевому споживачеві органічної продукції та іiі сертифікації. У 2013 р. виробники сертифікованої органічної продукції утворили спілку «Органічна Україна» з метою наповнення вітчизняного ринку якісними та безпечними харчовими продуктами [12].

За оцінками експертів, нинішні темпи розвитку органічного виробництва в Україні в 5,5 раза вищі за європейські та у 4,9 раза вищі за світові. Протягом останніх п'яти років загальна площа органічних сільськогосподарських земель зросла в 1,5 раза і Україна посіла 20 місце у світі й 11 місце серед європейських країн за загальною площею сільськогосподарських угідь, сертифікованих як органічні. У той же час органічні землі займають менше 1\% від 42,3 млн га сільськогосподарських земель в Україні. Але за збереження загальної позитивної тенденції розвитку органічного агровиробництва в Україні у 2020 р. площа органічних сільськогосподарських культур може збільшитися до 507 тис. га.

Нині переважна більшість сертифікованих органічних господарств в Україні зосереджені у Київській та Одеській областях - понад $10 \%$ у загальній кількості операторів органічного виробництва, у Харківській, Херсонській, Житомирській, Хмельницькій, Вінницькій, Чернігівській областях - до 10\%, в інших областях до 5\% [16]. У 2017 р. майже половина угідь загальною площею до 400000 га були зайняті під вирощування зернових, близько чверті - олійними і зернобобовими, 
решта - овочеві і ягідні плантації та сади [12]. У 2018 р. кількість операторів органічного ринку зросла до 617 (у 2014 р. було 400). Вже у 2014 р. наша держава за обсягами виробництва органічних продуктів посіла 20 місце в світі. Обсяг органічної продукції на внутрішньому ринку зріс до 500 млн грн. За даними швейцарсько-українського проекту «Розвиток органічного ринку в Україні» Дослідного інституту органічного сільського господарства (FiBL), [16] в Україні виробляється понад 400 найменувань органічної продукції, з них у 2018 р. Україною було експортовано понад 70 різних органічних товарів у 40 країн світу. Нині Україна займає 4 місце серед країн експортерів до СС. Обсяги експорту органічної продукції в $Є С$ за 2018 р. становили 266,7 тис. тонн. 3 усього обсягу продажів органічних продуктів 90\% припадають на експорт і лише 10\% - на внутрішній ринок. Найбільше українські органічні продукти купують Нідерланди, Німеччина, Англія, Литва, Австрія, Італія, Франція. Серед країн колишнього СРСР Україна посідає перше місце за обсягами експорту органічної продукції в країни ЄС. Основні види органічних продуктів, які експортують з України: пшениця, кукурудза, спельта, ячмінь, жито, соя, горох, насіння соняшнику та ріпаку, чорниця та малина (заморожені), яблука і яблучний сік (концентрат), просо і пшоно, мед, гриби, горіхи, трави та інші продукти [17]. Вперше з України почати експортували органічний мед у 2017 p., а у 2018 р. обсяги вже зросли до 300 тонн. Обсяг експортованої замороженої малини також значно зріс за останні 3 роки і в 2019 р. досяг понад 400 тонн. Все більше українських операторів експортують не тільки органічну сировину, але й готову продукцію. Так, у 2018 р. значно збільшився експорт органічної соняшникової олії. 3'явився перший український виробник органічного цукру ТОВ «Дедденс Агро», який став основним на європейському ринку органічного цукру з обсягом виробництва понад 800 тонн.

На внутрішньому ринку обсяги споживання органічної продукції у перерахунку на одну людину складають усього 0,68 євро (у світі сягає 10-11 євро) за доволі широкого асортименту органічної продукції. Однак ціни на органічні продукти в українських супермаркетах, зазвичай, суттєво завищені. Якщо за кордоном націнка в середньому становить 20-30\%, то в Україні iї величина - до 300\% [17], що суттєво знижує доступ органічних харчових продуктів для пересічного українця.

Значною подією стало набуття 2 серпня 2019 р. чинності Закону України «Про основні принципи та вимоги до органічного виробництва, обігу та маркування органічної продукції» [20], у якому врегульовано відносини у сфері органічного виробництва та обігу органічної продукції, що виробляється, ввозиться на митну територію України або вивозиться з неї в митному режимі експорту. Законом також визначено засади правового регулювання в Україні функціонування ринку, прав та обов'язків його суб'єктів, міжнародного співробітництва України у сфері органічного виробництва. До галузей органічного виробництва віднесено органічні рослинництво, тваринництво, грибництво, аквакультуру, виробництво морських водоростей, органічних харчових продуктів та органічних кормів. Також уведено контроль і реєстрацію операторів органічного виробництва й акредитацію сертифікаційних органів, які мають право працювати відповідно до українського законодавства. Створено Єдиний реєстр виробників органічної продукції, вже існує банк компаній ТОП Organic, які займаються органічним землеробством. Нові правила ведення господарської діяльності у сфері органічного виробництва дадуть змогу знизити рівень забруднення атмосферного повітря, води, земель синтетичними речовинами, 
у тому числі агрохімікатами, пестицидами, а також відходами тваринництва, сформувати якісні умови утримання певних видів тварин для задоволення їхніх поведінкових потреб.

Наказом Мінагрополітики від 22.02.2019 №67 затверджено державний логотип для органічної продукції. Також визначені умови для виробництва органічного молока та м'яса: годувати дорослих тварин дозволено лише органічними кормами, а молодих тварин - лише натуральним молоком. Молочне стадо повинне мати вільний доступ до пасовищ. У репродуктивний період тварин заборонено застосовувати гормони. Харчовий продукт має сертифікуватися не лише за виробничим циклом, але й за процесом одержання продовольчої сировини.

Більшість органічних операторів в Україні вже сертифіковані згідно з органічним стандартом СС (еквівалентним Регламентам СС №834/2007 та №889/2008) для використання як для експорту, так і для внутрішнього ринку. У той же час положення Закону про виробництво й обіг органічної сільськогосподарської продукції та сировини не в повній мірі забезпечують належну діяльність ринку органічної продукції, що створює умови для введення в обіг фальсифікованої органічної продукції та уникнення відповідальності за ці порушення.

Також слід акцентувати увагу і на певних соціальних перевагах органічного виробництва, яке створює додаткові робочі місця у сільській місцевості за менш екстенсивних і більш працеємних органічних технологій вирощування культур та розведення худоби. Водночас слід зазначити, що багато перешкод виникає ще на етапі виробництва органічної продукції сільгоспвиробниками. І серед найвагоміших можна виділити такі:

- відсутність державної підтримки органічного виробництва;

- складна, тривала і вартісна процедура сертифікації угідь, важкий процес переходу від традиційних технологій до органічного землеробства через тривалий простій землі задля іï регенераціїі і збити у зв' язку з цим;

- обмежена кількість екологічно чистих територій, які відповідають вимогам для вирощування органічної продукції;

- відсутність сучасних біотехнологій боротьби із шкідниками та органічних добрив;

- низький рівень знань і практичного досвіду ведення органічного господарства, відсутність підготовлених фахівців з цих питань;

- відсутність науково обгрунтованих технологій з виробництва та переробки органічної сільськогосподарської продукції;

- низькі закупівельні ціни комерційних посередників i, відповідно, низька дохідність господарства;

- відсутність маркетингових досліджень у сфері органічного виробництва;

- відсутність суттєвих інвестицій в органічну галузь;

- недостатній рівень транспортного забезпечення міжнародних перевезень;

- дисбаланс між експорто- та імпортомісткістю економіки.

Доволі суттєвими чинниками, які істотно гальмують прогрес розвитку ринку органічних продуктів в Україні, є також важкість проходження процедури сертифікації продукції за стандартами $\mathrm{CC}$, низька обізнаність виробників сільгосппродукції стосовно переваг і перспектив органічного виробництва, великі торговельні надбавки на органічні продукти харчування, недостатня інформованість населення про користь споживання органічних продуктів [21] .

Для успішного розвитку органічного виробництва в Україні потрібно передусім на державному рівні розробити та прийняти відповідні підзаконні акти, що дозволять виробникам прозоро проходити процедуру органічної сертифікації не тільки 
за чинними міжнародними, але й національними стандартами. Також важливою є діяльність для створення передумов із забезпечення інвестиційно-інноваційної моделі розвитку аграрних підприємств. Органічні продукти слід зробити доступними для вітчизняних споживачів за підвищення обсягів виробництва органічних харчових продуктів і зниження високих торговельних націнок на них у торговельній мережі.

Важливими є також зміцнення конкурентних позицій на ринку органічної продукції, запозичення досвіду іiі виробництва у високорозвинутих країнах світу та поглиблення інтеграції в міжнародний економічний простір.

Не останню роль відіграє і широка пропаганда здорового способу життя та здорового харчування, рекламування безпечної та корисної органічної продукції, а також започаткування в установах вищої освіти і галузевої науки спеціальної фахової підготовки, формування вітчизняної наукової школи для розробки інновацій у сфері виробництва органічної продукції.

Отже, виробництво органічної продукції в Україні має всі можливості для успішного розвитку. Подолавши деякі чинники, що гальмують цей процес, наша держава отримає гарні перспективи розвитку не тільки внутрішнього, але й експортного ринку органічних продуктів.

Перспективи подальших досліджень будуть спрямовані на розроблення удосконалення комплексної інтегральної оцінки ефективності органічного аграрного виробництва та створення науково-методологічної бази для започаткування принципово нових напрямків у науковій діяльності вітчизняних вчених, які працюють у сферах сільськогосподарського виробництва і харчових технологій.

Висновки. Виробництво органічної продукції є актуальним для багатьох країн світу, зокрема для України, яка має всі передумови увійти до числа лідерів з органічного виробництва.

Органічне виробництво може стати одним 3 найперспективніших напрямків діяльності у сільському господарстві та харчовій промисловості, що сприятиме збільшенню інтересу імпортерів до української продукції.

Для успішного розвитку органічного виробництва потрібна підтримка держави, спрощення процедури сертифікації угідь, запозичення досвіду виробництва органічної продукції у високо розвинутих країнах.

Наукові дослідження та просвітницька діяльність у сфері органічного виробництва $є$ вкрай необхідними для підвищення конкурентоздатності вітчизняної продукції на міжнародному ринку.

\section{ЛІТЕРАТУРА}

1. A study on awareness of organic food products in Trichy district / B. Rock, K. Puhalenthi, S. Vishnupriya [et al.] // Int. J. Community Med. Public Health. — 2017. — 4(12). - P. 4490 4494.

2. Білоткач I. А. Інституціональне забезпечення розвитку інфраструктури ринку органічної сільськогосподарської продукції / І. А. Білоткач // Інвестиції: практика та досвід. — 2019. № 3. - C. $12-20$.

3. Мартинюк М. П. Державне регулювання органічного виробництва: стан та перспективи розвитку / М. П. Мартинюк // Матеріали доповідей учасників V Міжнародної науковопрактичної конференції «Органічне виробництво і продовольча безпека». - Житомир: ЖНАЕУ, 2017. - C. 5-10.

4. Милованов Є. В. Регіональна підтримка органічного агровиробництва у світі / Є. В. Милованов // Науковий вісник Ужгородського Університету. - 2018. - Серія Економіка. Випуск 2 (52). - С. $63-74$.

5. Буга Н. Ю. Перспективи розвитку органічного виробництва в Україні / Н. Ю Буга, I. Г. Яненкова // Актуальні проблеми економіки. — № 2 (164), 2015. — С. 117 -125. 
6. Healthy food is nutritious, but organic food is healthy because it is pure: The negotiation of healthy food choices by Danish consumers of organic food /K. Ditlevsen, P. Sandoe, J. Lassen // Food Quality and Preference. - Vol. 71, January 2019. — P. 46-53.

7. Productivist or multifunctional: An activity theory approach to the development of organic farming concepts in Sweden / W. Świergiel , M. P. Querol, B. Rämert, M. Tasin [et al.] // Agroecology and Sustainable Food Systems. - Vol. 42, 2018. - Issue 2. - P. 210-239.

8. Органическое земледение - здоровье почвенной экосистемы / Т. Г. Алиев, Л. И. Кривощеков, В. В. Шелковников и др. // Экологическая педагогика: проблемы и перспективы вв свете развития технологий индустрии. Материалы Международной научной школы. Под ред. Е. С. Симбирских. - Мичуринск, 26 октября 2017. - С. 16-19.

9. Human health implications of organic food and organic agriculture: a comprehensive review / A. Mie, H. R. Andersen, S. Gunnarsson [et al.] // Environ Health. — Oct. 27. 2017. — 111 p.

10. Invited review: Organic and conventionally produced milk - An evaluation of factors influencing milk composition / B. H. Schwendel, T. J. Wester, P. C. Morel [et al.] // J. of Dairy Sci. Vol. 98, Issue 2, February 2015. - P. 721-746.

11. Buying 'Organic' to Get 'Authenticity'? Or Safer and More Nutritious Food? Think Again. And Again / Henry I. Miller. // Mo Med. - 2019. — Jan-Feb; - 116(1). - P. 8-11.

12. Вінюкова О. Б. Ринок органічної продукції в Україні: проблеми та перспективи розвитку / О. Б. Вінюкова, Г. А. Чугрій // Причорноморські економічні студії. — 2018. - Вип. 26. C. $42-47$.

13. Уланчук В. С. Розвиток органічного виробництва в Україні / В. С. Уланчук, О. В. Жарун, С. Ю. Соколюк, С. П. Ткачук // Молодий вчений. - 2017. - № 3. - С. $867-870$.

14. Правила для виробників сертифікованої органічної продукції // Офіційний сайт Федерації органічного руху України [Електронний ресурс] - Режим доступу: http:www. organic.com.ua/uk/homepage.

15. Механізм забезпечення розвитку органічного аграрного виробництва в Україні / Н. Ляліна, Г. Матвієнко-Біляєва // Agricultural and Resource Economics: International Scientific E-Journal. - 2019. - Vol. 5, No. 2. - P. 121-140.

16. Розвиток органічного ринку - Україна та світ/ FiBL. Інформаційний бюлетень. Березень. 2018 р. - 40 c.

17. Органік бізнес-довідник України. / за ред. Наталія Прокопчук (FiBL), Тетяна Зігг (FiBL), Юлія Власюк (FiBL). — К.: ФОП Михайло Лесін, 2014. — 406 с.

18. Регламент Ради (СС) № 834/2007 від 28 червня 2007 року про екологічне виробництво та маркування екологічної продукції і про 9 припинення дії Регламенту ЄЕС № 2092/91 [Електронний ресурс]. — Режим доступу: https://minjust.gov.ua/file/32349

19. Organic Standards and Certification / Офіційний сайт International Federation of Organic Agriculture Muvements [Електронний ресурс]. — Режим доступу: http://www.ifoam.org/about_ifoam/standards/index.html.

20. Закон України «Про виробництво та обіг органічної сільськогосподарської продукції та сировини». Відомості верховної Ради України. - 2014. - № 20-21. - С. 16-41.

21. О. В. Скидан. Формування регіональної політики ровитку органічного виробництва / О. В. Скидан // Органічне виробництво і продовольча безпека. Житомир: Видавець О. О. Євенок, 2016. - C. 16-26.

\title{
СОВРЕМЕННОЕ СОСТОЯНИЕ И ПЕРСПЕКТИВЫ РАЗВИТИЯ РЫНКА ОРГАНИЧЕСКОЙ ПРОДУКЦИИ В УКРАИНЕ И МИРЕ
}

\author{
И. Г. Власенко, Т. В. Семко \\ Винницкий торгово-экономический институт КНТЭУ \\ Г. Е. Полищук, М. П. Боровая \\ Национальный университет пищевых технологий
}

Целью научного исследования является анализ современного состояния и определение тенденций дальнейшего развития производства органической продукции в Украине и мире. В статье писана история возникновения отечественной 
отрасли органической продукции, ее становление и особенности адаптации к требованиям мирового рынка. Определены основные задачи отрасли как целостной системы хозяйствования и производства продовольственного сырья и пищевых продуктов. Подтверждена актуальность производства органической продукции во многих странах мира и Украине, которая имеет все условия для вхождения в число лидеров-производителей органических продуктов. Приведены достижения органического производства в Украине за последние годы и доказан ее значительный потенциал в данной сфрере экономической деятельности. Доказано, что реализация рекомендованных мероприятий будет всесторонне развивать рынок органической продукции, повышать его экспортную привлекательность, социальную значимость и удовлетворять потребность в здоровом питании отечественных потребителей.

Ключевые слова: здоровое питание, аграрный сектор, пищевая промышленность, органическое производство, органическая продукция. 